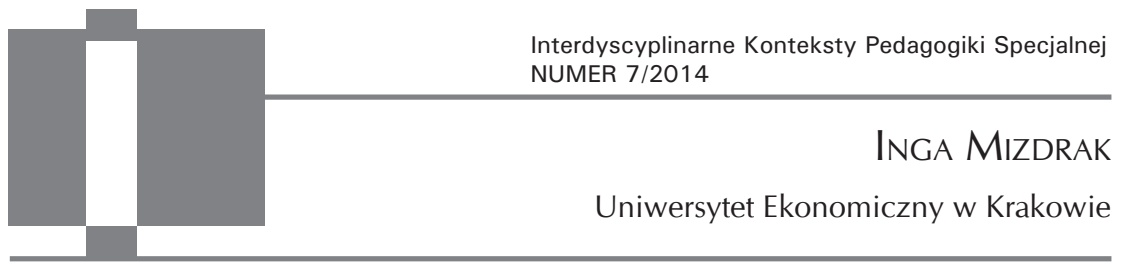

\title{
Podobny w inności i inny w podobieństwie - rzecz o spotkaniu innego w ujęciu Józefa Tischnera
}

\begin{abstract}
Aвsтract: Mizdrak Inga, Similar in otherness and other in similarity: Józef Tischner on the encounter with the other [Podobny w inności i inny w podobieństwie - rzecz o spotkaniu innego w ujęciu Józefa Tischnera]. Interdyscyplinarne Konteksty Pedagogiki Specjalnej, nr 7, Poznań 2014. Pp. 57-71. Adam Mickiewicz University Press. ISBN 978-83-232-2901-8. ISSN 2300-391X.
\end{abstract}

Otherness is encountered, noticed and, as the case may be, analyzed in a relation, because it is in a relation that the identity of I and the identity of You is revealed, and our identity is basically rooted in the individual constitution of a specific I and a specific You. The aim of the present study is to probe the phenomenon of otherness (alterity), and through it the fundamental question of who is the other we encounter, and next to show the main ways of experiencing the encounter with the other, which always occurs in the sphere of good and evil. In Józef Tischner's view the experience of the other is a fundamental one, in that it reveals much of our own self-experience. My encounter with the other also throws into relief myself as the other and the fact that his otherness is different from mine. In the beginning of this discovery of otherness, the gap between I and You appears to be unbridgeable. But Tischner believes that the sensation of separateness and even of "being alien" assumes a kind of similarity, with the proviso that the latter occurs on the plane of our mutual being for each other. Tischner stresses otherness in similarity and similarity in otherness, both constituted and coexistent in the relation between I and You. Tischner's idea involves a paradox: to open oneself to the alterity of the other, we have in a way to "bear" our own otherness and thereby to come to be "for the other".

KEY words: other, experience, relation, difference. 
Inny jako kategoria filozoficzna został niejako wydobyty z wielowiekowego przywiązania myślicieli do dwóch paradygmatów: arystotelesowskiego (przedmiotowego) i kartezjańskiego (podmiotowego). Dokonało się to dzięki filozofom dialogu, którzy w sposób szczególny zajęli się analityką Ty, przyczyniając się do powstania trzeciego paradygmatu myślowego, w którym słowo „jesteś”, obok dwóch pierwszych słów pierwszej filozofii (,,jest” i ,jestem”), nadało pełniejszy wymiar rozumieniu człowieka w świecie. Przejście do trzeciego paradygmatu nie oznacza jednak odejścia od poprzednich, lecz kontynuację i rozwój myślenia, w którym Ty staje się dopełnieniem Ja, ale także wezwaniem do odpowiedzialności. Nowy paradygmat myślowy nie polega jedynie na odkryciu nowej figury intelektualnej, która miałaby zastąpić lub uzupełnić poprzednie, bowiem Ty nie jest korektą Ja, lecz realnym i wydarzającym się w relacji bytem, który nosi w sobie własną troskę bycia i biedę, domagające się odpowiedzi ze strony drugiego ${ }^{1}$.

Głównym celem niniejszego opracowania jest scharakteryzowanie fenomenu inności na gruncie międzyosobowego spotkania, gdzie dwa różne $J a$, tożsame $\mathrm{w}$ sobie, w doświadczeniu siebie nawzajem, nie odkrywają tylko różnic, lecz i podobieństwa. Ważne jest więc ukazanie podstawowych sposobów doświadczenia innego w ujęciu agatologiczno-aksjologicznym, gdyż spotkanie dokonuje się w horyzoncie dobra i zła, nieustannie obecnego w życiu człowieka.

Myśląc o innym, myślimy najpierw o kimś, kto jest inny ode nas. Dostrzegamy różnice, gdyż siebie mamy najbliżej, wiemy, jak wy-

1 Na ten aspekt zwraca uwagę Jacek Filek w Filozofii odpowiedzialności XX wieku, gdzie pojęcie odpowiedzialności traktuje na równi z pojęciem prawdy i wolności. Według niego w owym trzecim paradygmacie myślowym zostały dopiero postawione pytania o istotę odpowiedzialności, ale nie stworzono jeszcze jej wykładni. Podano tylko pewne intuicje, które problematyzują kwestię odpowiedzialności. Filek podkreśla walor responsoryczności, czyli odpowiadania. W takim ujęciu odpowiedzialność oznacza odpowiadanie na zagadnięcie, a bycie zagadniętym nie tylko domaga się odpowiedzi "na”, lecz przechodzi w odpowiadanie „za”. Por. J. Filek, Filozofia odpowiedzialności XX wieku, Wydawnictwo Uniwersytetu Jagiellońskiego, Kraków 2003, s. 10-13. 
glądamy, jak się zachowujemy, jakie mamy wady i zalety; jesteśmy bowiem „nieprzenośni poza własne ja”. Inny jawi się zatem jako „nie-ja”, jako różny ode mnie. A jednocześnie dostrzegamy ów inny jest jakoś do mnie podobny i choć nie potrafimy od razu dostrzec tego podobieństwa, wyczuwamy je, choćby przez sam fakt istnienia w świecie. Mamy zatem pewną możliwość realnego poznawczego uchwycenia innego.

Nie można odkryć inności inaczej, niż napotykając ją wokół. Spotkanie inności, dostrzeżenie jej czy ewentualna analiza następuje $\mathrm{w}$ relacji - $\mathrm{w}$ niej bowiem dochodzi do odsłonięcia tożsamości zarówno $J a$, jak i Ty, a tożsamość osadzona jest w indywidualnej strukturze bytowej konkretnego Ja i Ty. Czy można jednak inność utożsamiać z innym? O jaką inność tutaj chodzi i o jakiego innego? Samo słowo „inny” zakłada inność, ale czy inność zakłada jednocześnie innego? Kim jest inny? Inny może być przecież nie tylko człowiek, ale i rzecz, zwierzę czy roślina. Czy inny to ktoś, kto przez swoją inność nieznany jest obcym? A jeśli inny to „ktoś”, to może przez swą osobową konstytucję nie jest obcy? Jeśli zaś nie jest obcy, to kim jest? Warto pokrótce określić zakres znaczeniowy tych pojęć, by nie wpaść w metodologiczną pułapkę bądź grę słowną.

Inność z jednej strony jest czymś danym, zastanym, niemal oczywistym dla każdego człowieka, jest bowiem obserwowalna, odczuwalna, doświadczalna, z drugiej zaś - intryguje i zaskakuje swą różnorodnością i odmiennością. Obszar inności obejmuje właściwie wszystkie płaszczyzny obcowania Ja i Ty. Wielość oblicz inności polaryzuje kwestię samego człowieka, który z racji swej osobowej i nieredukowalnej tożsamości zawsze pozostaje innym względem ludzi, świata, Boga.

Afirmacja i obsesja inności widoczne są w sztuce, poezji, filozofii, występują w ideologiach, modach, naukach, mając często psychologiczne (emocjonalne) podłoże. $Z$ jednej strony zachwyt, podziw, wdzięczność, wzruszenie innością, a z drugiej - zazdrość, pogarda, szyderstwo, splugawienie inności tworzą dialektyczny ruch, w którym spotykają się takie kategorie, jak: inny, obcy, bliźni. 
Według jednej z głównych tez, a zarazem założeń XX-wiecznych filozofów dialogu (Franza Rosenzweiga, Martina Bubera, Emmanuela Levinasa, Józefa Tischnera) inny i jego „inność” wydarza się w spotkaniu. Poprzez nie i w nim następuje „zderzenie” inności Ja i Ty, którzy stoją odtąd w obliczu innego, który pojawił się na ich drodze ${ }^{2}$. To czasoprzestrzenne wydarzenie ma charakter niepowtarzalny, wyjątkowy i w pewnym sensie radykalny, ale równocześnie dramatyczny, bo rozgrywa się w nim wolność człowieka, a w tej wolności walka o siebie nawzajem.

Filozofia dialogu w swych rozmaitych odmianach mówi zasadniczo o poznaniu siebie poprzez drugiego, uwydatniając możliwość zgłębiania świata z perspektywy drugiego, a zatem wychodzi poza metafizykę podmiotowości w nowy paradygmat myślenia, gdzie Ty staje się nie tylko polem odniesień, ale również przedpolem rozumienia i odnajdywania sensu. Perspektywa innego silnie uwydatniła się właśnie dzięki XX-wiecznym dialogikom, którzy dokonali nie tylko przejścia, ale wręcz odejścia od kartezjańskiego ego cogito, pokazując, że aby spojrzeć na faktyczną inność innego i jego odrębność od świata przedmiotów, należy wyjść poza własny sposób patrzenia na rzeczywistość i spojrzeć na nią oczyma drugiego, bo być może on lepiej potrafi opisać strukturę rzeczywistości i mnie samego. Ów inny ma zatem fundamentalne znaczenie w poznawaniu, rozumieniu i odsłanianiu rzeczywistości.

Józef Tischner wiele miejsca w swojej twórczości poświęca fenomenologicznym analizom innego, ustalając nie tylko to, kim i jakim jest inny, ale i to, w jakim horyzoncie odsłania się jego Ja. Ja innego pojawia się bowiem zawsze $\mathrm{w}$ relacji dialogicznej. Nie ma zatem Ja bez Ty ani Ty bez Ja.

W Filozofii dramatu Tischner podkreśla konieczność przejścia, a nawet rezygnacji z opisu Ja na poziomie ontologii, optując za po-

${ }^{2}$ Na temat współczesnej filozofii spotkania zob. J. Bukowski, Zarys filozofii spotkania, Znak, Kraków 1987; A. Węgrzecki, Wokót filozofii spotkania, WAM, Kraków 2014; D. Kot, Podmiotowość i utrata, Znak, Kraków 2009; T. Gadacz, Historia filozofii XX wieku. Nurty, t. 2, Znak, Kraków 2009; M. Jędraszewski, Wobec innego. Relacje międzypodmiotowe w filozofii Emmanuela Levinasa, Księgarnia św. Wojciecha, Poznań 1990. 
ziomem aksjologicznym, na którym Ja uwydatnia się jako wartość. Dla Tischnera dopiero właśnie ten poziom „dotyka samego rdzenia doświadczeń egotycznych"3 ${ }^{3}$. Ja jest wartością samą w sobie, ale i wartością dla drugiego. Ma wartość własną jako osoba, ale i stanowi wartość dla innych. Pierwszeństwo aksjologii przed ontologią jest dla Tischnera w opisie człowieka właściwym punktem wyjścia: "Ja aksjologiczne jest, bo jest ważne. Ale nie dlatego jest ważne (ma swą wagę, ma swe znaczenie), że jest". Czy można zgodzić się z Tischnerem? Czy nie jest bowiem tak, że z samego faktu, że Ja jest, nie wypływa jego wartość, waga i znaczenie? Czy poziom ontologii ma być zniesiony (wyparty) przez poziom aksjologii? Czy oba nie zachodzą jakoś na siebie?

Tischner dostrzega owe trudności, ale konsekwentnie broni stanowiska, że aby dotrzeć do istoty Ja i Ty, nie można zatrzymać się na pytaniach o byt, lecz wejść w obszar pytań o wartości, które się przyswaja, uznaje, wybiera. „Gdy mówię Ja - jestem wartością dla siebie. Gdy słyszę, że ktoś do mnie mówi Ty - wiem, że jestem »ważny« dla niego. I wtedy również on staje się ważny dla mnie" ${ }^{4}$. Bycie wartością dla drugiego i posiadanie własnej wartości jest czymś uniwersalnym, nie znikają one bowiem wraz z jakimś, choćby najbardziej skrajnym i trudnym, wydarzeniem. Bycie wartością to nie to samo co bycie wartościowym (np. z jakiegoś punktu widzenia czy w jakiejś dziedzinie), choć się z tym łączy. Być Ja aksjologicznym to znaczy być nim w radykalnym tego słowa znaczeniu, bo Ja „posiada ważność uniwersalną: może i powinno być uznane w swej wartości zawsze oraz przez wszystkich" ${ }^{5}$. Uznanie to może dopełnić się w spotkaniu. Ja uznaje Ty, a Ty uznaje Ja. Uznanie nie miałoby miejsca, gdyby nie było relacji, a relacja nie wystąpiłaby, gdyby nie było spotkania i doświadczenia innego. Z kolei uznanie nie mogłoby się dokonać, gdyby nie wolność człowieka, a ta zawsze dokonuje się w horyzoncie

\footnotetext{
3 J. Tischner, Filozofia dramatu, Kraków 2006, s. 79.

4 Ibidem, s. 81.

${ }^{5}$ Ibidem.
} 
dobra i zła. Jedynie „dzięki takim horyzontom może zaistnieć Ja jako Ja aksjologiczne - jako wartość"6.

Dla Józefa Tischnera doświadczenie innego jest podstawowe, bo odsłania również wiele z samodoświadczenia. Jeśli napotykam innego, to odkrywam, że sam jestem inny oraz że inny jest inny niż ja. Ale choć jestem daleki od niego, to dostrzegam pewną bliskość innego, i odwrotnie: on jest jakoś daleki ode mnie, jest przeciwieństwem mojej tożsamości, a zarazem jest mi jakoś bliski, a ja jemu‥ Mogę mieć jednak poczucie, że moja osobność i wsobność jest radykalna. Wobec odkrycia inności dystans między Ja i Ty może wydawać się nie do pokonania. Tischner sądzi jednak, że osobność, a nawet „obcość" zakłada pewne podobieństwo, z tym że jest ono obecne na płaszczyźnie bycia dla siebie. „Gdybyśmy gdzieś w głębi nie czuli, że jesteśmy dla siebie, nie wiedzielibyśmy, że chodzimy obok siebie"8. Można zatem odkryć taki rodzaj podobieństwa do innych, który rozciąga się paradoksalnie na inność wszystkich. Najlepiej oddaje to kategoria bliźniego, a więc innego, który nie musi być mi bliski w znaczeniu więzów krwi, podobnej kultury, języka, wyznania, światopoglądu, a nawet psychologicznie czy duchowo, a mimo to jest kimś, kto z samej racji tego, że jest tym, kim jest, jest bliźnim (bratem, przyjacielem).

Tischner podkreśla różnicę między „innym” a „różnym”, choć ma świadomość ograniczonych narzędzi dostępnych w języku polskim i w związku z tym wskazuje na nie do końca precyzyjne znaczenie słowa "inny"9. Według niego zgoda na zrównanie słów „inny” i "różny" reifikowałoby podmiotowy charakter bytu ludzkiego. Świat odmiennych osób to coś więcej niż zróżnicowanie biologiczno-estetyczno-jakościowe. Jak zaznacza Tischner, „inny” to nie „różny”. W odniesieniu do osoby nie można używać takich samych kategorii, jak w relacji do przedmiotów, rzeczy. „Różny” może być stól, kwiat, kot, natomiast „inny” to ktoś, kto „nie jest rzeczą między rzeczami

6 Ibidem.

7 M. Bardel, Różne twarze inności, „Znak” 2004, nr 584(1), s. 13.

8 J. Tischner, Spór o istnienie człowieka, Kraków 2011, s. 258.

${ }^{9} \mathrm{Wj}$. polskim brakuje wyraźnej dystynkcji między „innym” przedmiotem a „innym" człowiekiem. 
ani przedmiotem między przedmiotami, lecz podmiotem, innym $J a$, który staje się dla mnie Ty lub On, z którym mogę wejść we wspólnotę $M y^{\prime \prime 10}$. To, że inny nie jest przedmiotem, nie wyklucza pokusy i możliwości uprzedmiotowienia go. Taka możliwość nie zostaje zniesiona nawet wówczas, gdy zawiązała się najbliższa relacja miłości.

Inny, którego spotyka Ja, również dostrzega różnicę między sobą a tym, którego spotkał. Relacja zwrotności poznawczej i doświadczenia jest cały czas obecna między podmiotami spotkania, ale to, co dla Tischnera stanowi jeden z jej najistotniejszych momentów, to dramatyczność spotkania. Inny „otwiera horyzont dramatu: wszelki dramat może być jedynie dramatem z innym - innego z innym"11. Tischner ma świadomość, że każde spotkanie niesie jakieś następstwa (pozytywne lub negatywne), a zatem każdorazowo dokonuje się ruch (wartości, znaczeń, sensów, gestów, spojrzeń, słowa) i ,zmiana znaczenia przestrzeni, w której znajduje się spotykający”"12. Skoro następuje zmiana, to to, co uprzednio zaistniało $\mathrm{w}$ tej przestrzeni, nie może przestać istnieć (np. konkretne wybory, odpowiedź na wartości, wypowiedziane słowa). Zmiana zakłada ponadto możliwość, a tam, gdzie istnieje możliwość, jest alternatywa oraz wybór - zarówno kierunku, jak i konkretnych wartości. Tischner widzi w przestrzeni spotkania także swoistą niemożność ucieczki - przed wolnością z jednej strony i przed innym - z drugiej. Spotykając drugiego, wiem, że zaistniał on już w przestrzeni mojej wolności, świadomości, historii, a zatem próba usunięcia go z niej jest $\mathrm{w}$ gruncie rzeczy niemożliwa (nawet gdy unicestwiam drugiego fizycznie bądź duchowo odsuwam). Zatem spotkany inny na zawsze już pozostanie - rzecz w tym, jaki ślad pozostawi na mojej drodze, a jaki ja na jego. Wniosek z tego jest następujący: wszystko, co Ja i Ty wnoszą w spotkanie, ma fundamentalne znaczenie (nie tylko dla samego spotkania, ale także dla jego podmiotów). Jeśli podmiotom relacji chodzi o prawdę i wnoszą ją w spotkanie, to ich więź kształtuje się na jej pod-

${ }^{10}$ J. Tischner, Inny, „Znak” 2004, nr 584, s. 17.

${ }^{11}$ J. Tischner, Spór o istnienie człowieka, Kraków 2011, s. 259.

12 J. Tischner, Inny, op. cit., s. 16. 
stawie. Jeśli zaś spotykające się podmioty są na usługach kłamstwa (lub jeden z nich), to ich spotkanie będzie nim na zawsze naznaczone. Tischner nie oskarża owej „nieusuwalnej dramatyczności” za wszelkie zło i nieprawdę obecne w relacji $J a-T y$, dostrzega jedynie, że główną rolę odgrywa w niej wolność człowieka. To wolność zakłada ruch „od-do". Tischner poetycko stwierdza, że "oglądamy własną wolność jako możliwy ruch na drodze”, a ruch ten przebiega zawsze na osi aksjologicznych uznań. W spotkaniu można dokonać wyboru dobra lub zła, można siebie wygrać albo potępić, iść w górę, ku niebu, lub w dół, ku potępieniu. Dramatyczność leżąca u podstaw relacji nieustająco o tym przypomina. Podobnie względem drugiego: można się zwrócić ku niemu albo od niego odwrócić. Nasza wolność nie znika nawet wtedy, gdy dokonaliśmy już pierwszego wyboru, dlatego że wolność człowieka jest zagrożona i człowiek musi ją stale na nowo zdobywać.

W analizie innego Tischner, podobnie jak inni dialogicy, uwydatnia znaczenie mowy, w którą wpisane są słowa: "Ja”, , "Ty", , "My". Inny to ten, z kim się komunikuje, rozmawia, wchodzi w spór, rozmowę, dialog. W spotkaniu i słowie odsłania się to, że Ty to "Ty", czyli osobowa wartość i godność drugiego. Nie tylko bowiem w wydarzeniu mowy i spotkania widoczne są wartości bliskie drugiemu i wybierane przez niego, ale i to, że ten drugi sam jest wartością i to wartością niezbywalną. Różnica między Ja i Ty ostatecznie sprowadza się do pierwotnej odrębności, którą w języku personalistów można określić jako „niezbywalną nieredukowalność podmiotową osoby”, w psychologii jako „,tożsamość strukturalną osoby”, a w słowach Tischnera po prostu jako „inność innego".

Tischner dokonuje też pewnego przejścia, bowiem pisze o zachowaniu przez Ja do końca swej tożsamości (a więc różnicy względem innego) pomimo podobieństw, i odwrotnie - zauważa podobieństwo drugiego pomimo nieusuwalnych różnic: „inny mieści w sobie paradoks: on jest inny niż ja, a jednak do mnie podobny - podobny $\mathrm{w}$ inności i inny $\mathrm{w}$ podobieństwie"13. Istnieje alteryczna i egotycz-

${ }^{13}$ Ibidem, s. 19. 
na strona doświadczenia innego i obie zachodzą na siebie. Tischner konstatuje: „inność innego wydobywa na jaw moją własną inność. Inność jest wzajemna. Inność zaskakuje, przynosi wciąż nowe niespodzianki, w całej przewidywalności jest nieprzewidywalna. Ciąg doświadczeń innego zamykają dwie granice: nigdy nie może dojść do tożsamości »nas « i nigdy nie może dojść do zupełnego zróżnicowania "między nami «"14. Jesteśmy zatem „sobą do końca, sobą nie do zmazania"15. Granica inności nie musi więc oznaczać niedostępności wobec drugiego, lecz tajemnicę indywiduum, gdyż jest on nieredukowalnym bytem, choć przez drugiego siebie poznającym. Doświadczenie inności mieści w sobie podobieństwo i niepodobieństwo: „inny jest kimś podobnym i zarazem niepodobnym [...]. Doświadczenie inności rozwija się jako bezustanne przechodzenie od jednej perspektywy do drugiej"16. Inni są różni, ale też w pewnym stopniu podobni do siebie, mogą zatem się do siebie zbliżać i poświęcać się sobie nawzajem. Inność bowiem intryguje, prowokuje, może być też zachętą do głębszego poznania i przyjaźni. Inność może również odrzucać, zniechęcać, powodować niezrozumienie i coraz większy dystans - wówczas można mówić o niepodobieństwie w podobieństwie i ukierunkowaniu na nieprzyjaźn ${ }^{17}$.

Inność podobieństwa w niepodobieństwie Tischner rozumie tak, że skoro inny jest w jakiś sposób do mnie podobny, to wydaje się zrozumiały, a tym samym bliski, a nawet „swojski”, co pozwala na uczestnictwo, większą bliskość i zrozumienie. Natomiast inność niepodobieństwa w podobieństwie polega na tym, że inny staje się coraz bardziej niezrozumiały, bo nie jest bliski czy "swojski”, a przez oddalanie się lub dalekość jest coraz bardziej niezrozumiały, a zatem pozostaje lub staje się obcy.

Inność rozumiana jako podobieństwo w niepodobieństwie oraz niepodobieństwo w podobieństwie tworzy wiele płaszczyzn, na któ-

\footnotetext{
14 Ibidem.

15 J. Tischner, Filozofia dramatu, op. cit., s. 82.

16 J. Tischner, Spór..., op. cit., s. 259-260.

17 Ibidem, s. 260.
} 
rych Ja i Ty dokonują wyborów. Ja i Ty mogą, ale nie muszą spotkać się na tej samej płaszczyźnie wartości, działań, myśli, uczuć, rozumienia świata. Mimo bliskości mogą być dalej dla siebie obcy, mimo więzi mogą nie tworzyć wspólnoty, mimo podobieństwa mogą całkowicie się różnić. Rozmaite poziomy i płaszczyzny spotkania, w którym uczestniczą Ja i Ty, zawsze oscylują wokół dobra i zła i może zdarzyć się tak, że nigdy na siebie nie zajdą ani nie uzupełnią się nawzajem. Co może zatem stanowić nadzieję na wspólnotę?

Specyfika Ja i Ty przejawia się w tym, że mogą mieć oni inny punkt widzenia na podobne sprawy, we własny sposób rozumieć sensy i znaczenia oraz internalizować wartości, dlatego „poznać innego jako innego i zarazem nie-innego znaczy uchwycić go w jego indywidualnym, wewnętrznym skręcie, określającym jego niepowtarzalny sposób przeżywania życia"18.

Tischner zauważa, że ów indywidualny sposób przeżywania świata może mieć postać przepaści między Ja i Ty, bowiem każdy z tych podmiotów odmiennie przeżywa i doświadcza rzeczywistości, siebie, innego oraz posługuje się odmiennym językiem opisu zjawisk, słowem - nie wiążą ich „żadne związki przyczynowe"19. W tej różnicy między nimi jest jednak coś, co powoduje, iż Ja i Ty jako monady zaczynają tworzyć "okna” otwierające się jedno na drugie. Otwierający charakter relacji Ja i Ty pojawia się w sytuacji pytania, które wytrąca dany podmiot z egocentrycznej monadyczności. Pytanie i odpowiadanie rozpoczyna rozmowy i dzieje Ja i Ty, które współbytując, mogą być poprzez siebie. Owo „poprzez” jest pełne znaków zapytania, ale i stwarza perspektywę rozwoju: „po pytaniu i po odpowiedzi - w ogóle: po rozmowie - nie jesteśmy już tacy sami, jacy byliśmy przedtem" 20 .

Kim są dla siebie Ja i Ty w spotkaniu? Czy są jedynie innymi, nawet jeśli w podobieństwie, i jedynie podobnymi w inności? Co oznacza bycie wezwanym przez innego?

\footnotetext{
18 J. Tischner, Inny, op. cit., s. 21.

${ }_{19}$ J. Tischner, Filozofia dramatu, op. cit., s. 77.

${ }^{20}$ Ibidem.
} 
Spotkanie nie ma jedynie konsekwencji, lecz rodzi też zobowiązania. W czasie spotkania pojawiają się pytania, a jeśli są pytania, to i oczekiwanie odpowiedzi. Odpowiedź ma być nie tylko naturalną reakcją na pytanie, ale staje się zobowiązaniem, wobec którego nie można pozostać obojętnym, gdyż „inny człowiek jest obecny przy mnie poprzez to, co trzeba, abym dla niego uczynił; i ja jestem przy nim obecny poprzez to, co trzeba, aby on uczynił dla mnie. Więź, która między nami powstaje, jest więzią zobo-wiązania. Zobo-wiązanie to wiązanie obowiązkiem" ${ }^{21}$. Wypełnienie tego obowiązku, a zatem udzielenie odpowiedzi, nie jest łatwe, bo Ja i Ty spotykamy się na styku naszych hierarchii, które wypełniają nasz los i ukierunkowują nasze działania. Według Tischnera dialog staje się prawdziwym dialogiem dopiero wtedy, gdy Ja i Ty uczestniczą w podobnej hierarchii lub przynajmniej gdy hierarchie Ja i Ty są w stanie się jakoś upodobnić do siebie.

To, że Ja i Ty przychodzą z wnętrza jakiejś hierarchii, nie oznacza jeszcze, że prawdziwie się spotkają. Wszystko, co wniosą w relację, w owo „między” siebie, będzie rzutowało na jej jakość. Mogą przecież wnieść całkiem różne wartości, które nigdy się „nie spotkają". Może być i tak, że choć ich dążenia były podobne, to gdzieś na styku czasu dramatycznego rozeszły się lub odwróciły od siebie. Może być też tak, że tylko jedna ze stron próbowała upodobnić własną hierarchię do hierarchii wartości innego, lecz ten na to nie pozwolił lub jego hierarchia była zupełnie odmienna. Warto więc ponownie zadać pytanie o wolność podmiotów spotkania, a także o odpowiedzialność, która całkowicie oczyszcza człowieka z egocentryzmu i egoizmu.

W filozofii dramatu Tischnera na pierwszy plan wysuwa się wolność innego, a nie moja własna, z kolei wolność Ty stanowi impuls dla mojej wolności, by dała odpowiedź na jego pytanie, troskę, problem. Jest więc tak, że drugi i spotkanie z jego wolnością wytrąca mnie z pasywności i kieruje na drogę zaangażowania mojej wolności, która nie może być odtąd swawolą czy samowolą, lecz dobrowolnym i odpowiedzialnym udzielaniem się drugiemu. Paradoks polega na

${ }^{21}$ Ibidem, s. 13. 
tym, że „jeśli dam odpowiedź, to tylko dlatego, że sam zechcę" ${ }^{\prime 22}$. Odpowiadając, korzystam ze swojej wolności, ale jednocześnie potwierdzam, że drugi jest przy mnie obecny jako pytający. Zatem udzielając mu z własnej woli odpowiedzi, staję się tym samym odpowiedzialny za niego. Jak pisze Tischner: „istotny sens pytania polega na tym, że budzi ono w zapytanym poczucie odpowiedzialności" ${ }^{23}$, a tym, co najważniejsze w wyborze i udzieleniu odpowiedzi jest nie tyle spełnienie etycznego zobowiązania, ile udzielenie odpowiedzi - innemu i samemu sobie jako „uczestnikowi dramatu dobra i zła”24. Należy udzielić odpowiedzi, aby nie zabić w drugim nadziei, aby nie unicestwić w innym jego biedy, z którą do mnie przychodzi. Konstatacja Tischnera radykalizuje konieczność udzielenia odpowiedzi: „Gdybym milczał, mógłbym dokonać zbrodni na twarzy pytającego. Moje milczenie byłoby aktem pogardy - metafizycznej pogardy, przeciwko której nie może argumentować żadna fizyka, żadna ontologia" ${ }^{25}$.

Zapytanie, które stawiam innemu, wzywa go do odpowiedzi, i odwrotnie: jego pytanie wzywa mnie do udzielenia mu odpowiedzi. Podstawą wezwania do odpowiedzi jest uznanie drugiego w jego wartości. Do czego może wzywać inny? Jeśli zadał mi pytanie, może wzywać do zainteresowania się jego losem, może też chcieć, bym lepiej zrozumiał jego troskę, lepiej wsłuchał się w nią i w jego samego, a więc stał się bytem „dla” niego. Może również wzywać mnie do tego, bym sam "stał się innym dla siebie samego" 26 , a zatem bym się przemienił, zmienił swój dotychczasowy sposób postępowania, mówienia, myślenia. Inny swoim pytaniem może również wzywać mnie do pojednania, a więc i przebaczenia krzywdy. Aby jakiekolwiek wezwanie mogło się urzeczywistnić w konkretnej odpowiedzi (w zależności od charakteru pytania), musi dokonać się specyficzny ruch $J a$, a nawet transformacja, która ma polegać na tym, iż "Ja nie

\footnotetext{
${ }^{22}$ Ibidem, s. 67.

${ }_{23}$ J. Tischner, Filozofia dramatu, op. cit., s. 68.

24 Ibidem.

25 Ibidem, s. 76.

${ }^{26}$ J. Tischner, Inny, op. cit., s. 22.
} 
mogę już być Ja-w-sobie-i-dla-siebie, lecz muszę się stać Ja-z-innym, a nawet Ja-dla-innego" ${ }^{\prime 27}$. Musi zatem nastąpić wyjście z własnego Ja (a także własnego egocentryzmu) nie tylko w stronę innego Ty, ale nawet „zawieszenie” własnego ego i wejście w inność Ty. Bycie bytem-dla-siebie dokonuje się zatem poprzez inne bycie-dla siebie i dlatego zarówno owo „dla-siebie”, jak i „poprzez” (tj. dla-siebie-nawzajem) stanowią fundament relacji. Dla Tischnera nie ma lepszej drogi poznania, doświadczenia, zrozumienia i prawdziwego dialogu z drugim. Słowa „dla” i „poprzez” zawierają się w czaso-przestrzeni dramatu, gdzie oba bycia-dla-siebie są podmiotami dramatu, ale także jakimiś w tym dramacie się stają. "Jesteśmy tacy, jaki jest nasz dramat" ${ }^{28}$. Czy zdania tego nie należałoby jednak odwrócić i powiedzieć, że taki jest nasz dramat, jacy jesteśmy? Tischner tego nie dostrzegł, ale miał świadomość, że obecne w życiu człowieka wartości dobra i zła na scenie dramatu toczą nieustanną walkę.

Filozof idzie w swych analizach jeszcze dalej, twierdząc, że aby otworzyć się na inność drugiego, muszę „znieść” własną inność, „zanurzyć", "zatopićc, „obumrzeć dla siebie” 29. Czy takie „zanurzenie” w drugim, „zatopienie" się w jego trosce, losie, życiu nie niesie ryzyka utraty siebie, zanegowania własnej tożsamości? Jeśli odtąd Ja nie jest już Ja, lecz staje się Ty dla drugiego, to czy nie traci jakoś siebie, a jeśli traci, to w jakim sensie: poświęcenia i ofiary czy może uległości i wygody?

Tischner poprzez te stwierdzenia nie usuwa różnicy między Ja i Ty i w wielu miejscach swojej twórczości mówi, że to, co należy do Ja (cały zestaw cech, przeżyć, uczuć, doznań, wyborów), jest jego, ale równocześnie jest przez to Ja przekraczane w stronę Ty. Ponadto nasza indywidualność nie unifikuje się we wspólnocie. Pozostaje ona mimo zjednoczenia, wzajemności, więzi. Tischnerowi chodzi zatem o dostrzeżenie tego momentu, w którym spotykają się dwa kwestionowania, będące jednocześnie wzajemnym potwierdzaniem siebie.

27 J. Tischner, Inny, op. cit., s. 22.

28 J. Tischner, Spór..., op. cit., s. 255.

29 J. Tischner, Inny, op. cit., s. 22. 
Tak rodzi się filozofia rozmowy, gdzie „ty kwestionujesz mnie, a ja mimo to potwierdzam ciebie $\mathrm{w}$ twoim akcie kwestionowania mnie. Znaczy to również, iż ty aktem swego pytania zakwestionowałeś siebie, aby uznać mnie w tym, co ci powiem"30. W innym miejscu Tischner $\mathrm{w}$ podobny sposób ujmuje sens takiego jednającego kwestionowania: „Nie tylko Ja jestem kwestionowany przez innego, lecz również inny przeze mnie. Wtedy Ty zanurza się i zatapia w moim $J a$, kwestionując swój skręt przeżywania świata, swą indywidualność. Kwestionowania biegną w obydwie strony, raz Ty staje się mną, raz Ja staje się nim. Nie ma tutaj stałej reguły. Granice dzielące $J a$ od Ty zamazują się" ${ }^{131}$. Z jednej zatem strony tożsamość $J a$ jest czymś utrwalonym, a z drugiej - czymś, co przechodzi w drugiego, bo dzięki owemu przechodzeniu Ja w Ty i Ty w Ja można naprawdę odkryć innego $\mathrm{w}$ sobie i siebie $\mathrm{w}$ innym. Zawarta $\mathrm{w}$ tytule niniejszego opracowania teza Tischnera znajduje tu swoistą kulminację: jestem inny w różnicy, ale i różny w podobieństwie. Nie tracę siebie, jakoś jednak "tracąc siebie". Jestem Ja, ale i nie jestem Ja. Jestem $J a$, ale przechodząc $\mathrm{w}$ drugiego, staję się nim w tym znaczeniu, że jego los, hierarchia, „skręt patrzenia na świat” stał się w jakiś sposób moim. Z pewnością owo „przejście” czy „wejście” w drugiego nie jest w pełni możliwe, gdyż wnętrze drugiego stanowi taką "głębię", do której dostęp ma jedynie Bóg. Dotarcie Ja do głębi Ty jest ograniczone i narażone na niepewność. Głębia drugiego może się jakoś odsłaniać, ale też skrywać, może objawiać prawdę Ja, ale i sobą kłamać drugiemu. Dialektyka prawdy i fałszu, jasności i ciemności, ułudy i rzeczywistości nieustannie objawia się na skrzyżowaniu dróg Ja i Ty i może jedynie „nagość twarzy, w której zogniskowała się cała ludzka bieda", jest tym, co ostatecznie owo podobieństwo inności zachowuje. Z kolei inność w podobieństwie wzywa do odpowiedzialności, a ta - do bycia darem dla innego.

Doświadczenie inności, obejmujące warstwę egotyczną i alteryczną, budzi jeszcze wiele pytań, ale Tischnerowskie intuicje prowadzą

${ }^{30}$ J. Tischner, Filozofia dramatu, op. cit., s. 77.

31 J. Tischner, Inny, op. cit., s. 22-23. 
do poznania relacji $J a-T y$, w której wzajemność i autentyczny dialog odpowiedzialności, miłości, obecności może stanowić zalążek $M y$, a więc wspólnoty, w której każdy z podmiotów w jakiś sposób upodabnia się do innych, przy zachowaniu własnej odrębności. $W$ fenomenie poświęcenia się dla drugiego, ofiarowania siebie, a nawet „zatracenia" siebie dla drugiego uwidacznia się charakterystyczny rys natury ludzkiej, która realizuje się nie tylko w sobości Ja $i$ sobości Ty, ale także w nieustannym „wychodzeniu” z własnej sobości w stronę drugiego, który czeka na odpowiedź będącą potwierdzeniem wspólnego spojrzenia na swoje dzieje, nadzieje i troski.

\section{Bibliografia}

BARDel M., Różne twarze inności, „Znak” 2004, nr 584(1).

BuKowski J., Zarys filozofii spotkania, Znak, Kraków 1987.

FiLeK J., Filozofia odpowiedzialności XX wieku, Znak, Kraków 2003.

Gadacz T., Historia filozofii XX wieku. Nurty, t. 2, Znak, Kraków 2009.

J̨̨DRASZEWski M., Wobec innego. Relacje międzypodmiotowe w filozofii Emmanuela Levinasa,

Księgarnia św. Wojciecha, Poznań 1990.

Кот D., Podmiotowość i utrata, Znak, Kraków 2009.

Tischner J., Filozofia dramatu, Znak, Kraków 2006.

TisCHNER J., Inny, „Znak" 2004, nr 584.

Tischner J., Spór o istnienie człowieka, Znak, Kraków 2011.

WĘGRZECKI A., Wokót filozofii spotkania, WAM, Kraków 2014. 